\title{
Relevance of Seed Bank in the Process of Recovery of the Atlantic Forest in São Paulo - Brazil in the Four Seasons of the Year
}

\author{
Maria Luiza Domingues Villar, Cleber Ferrão Corrêa, Heloisa de Oliveira Zanella
}

Department of Environmental Engineering, Catholic University of Santos, Santos, Brazil

Email address:

mvillar@unisantos.br (M. L. D. Villar), cleberferrao@unisantos.br (C. F. Corrêa), heloisa.zanella@unisantos.br (H. de O. Zanella)

\section{To cite this article:}

Maria Luiza Domingues Villar, Cleber Ferrão Corrêa, Heloisa de Oliveira Zanella. Relevance of Seed Bank in the Process of Recovery of the Atlantic Forest in São Paulo - Brazil in the Four Seasons of the Year. International Journal of Environmental Monitoring and Analysis. Vol. 5, No. 4, 2017, pp. 109-115. doi: 10.11648/j.ijema.20170504.13

Received: June 6, 2017; Accepted: July 15, 2017; Published: August 2, 2017

\begin{abstract}
One of the planet's richest areas in biodiversity can be found in Brazilian territory: the Atlantic Forest, which is also an example of the most severe devastation cases. Spread in an area larger than $30.000 \mathrm{~km}$ and $30^{\circ}$ degrees latitude, it is categorized as tropical rainforest. Due to the planting of monocultures such as sugarcane and coffee as well as the urban development, there are only $7.5 \%$ left of its original area which comprises $2 \%$ of all vegetation species and vertebrate animals in the planet. The region is also among the five most important hotspots of biodiversity which justifies the understanding of all natural regeneration processes through the knowledge provided by a soil seed bank. This work describes the contents of the bank by the identification of seedlings through the seasons of the year, thus contributing with information on the natural recovery of this biome.
\end{abstract}

Keywords: Atlantic Forest, Seed Bank, Identification of Seedlings

\section{Introduction}

Brazil stands out as one of the countries with the largest biodiversity in the world, having around 357 million acres of tropical forests, $30 \%$ of all in the planet and more than double the number in the second ranked country, Indonesia [1]. Tropical forests have a great importance in the preservation of biodiversity as well as in the acquisition of assets and services provided directly or indirectly by these ecosystems. Just as an example is the preservation of the quality of life of humankind globally. Despite their relevance, the future of tropical forests remains uncertain [2].

In Brazil one of the planet's richest areas in biodiversity can be found, and mentioned as well as one of the most devastated: the Atlantic Forest. This biome covers over $3.000 \mathrm{~km}$ and $30^{\circ}$ latitude, presenting the largest latitudinal reach among the great ecological regions in Latin America. It spreads from the Brazilian Atlantic coast to the parallel 603 [3].

This biome is categorized as a rainforest, situated mostly between the tropics of Cancer and Capricorn, considering that in Brazil the rainforests are found in the Amazon Basin and in the remains of the Atlantic Forest [4].

The devastation of the Atlantic Forest started centuries ago and it is closely linked to the economic history of Brazil. In every economic cycle one parcel of the forest disappeared from its total extension. This process had its beginning in the colonial period, with the Portuguese colonizers, through the exploitation of all greenery; thus, in the next centuries, by the use of the land in agriculture, mostly sugarcane and coffee, and later on by the unplanned urban sprawling [5]. As a result, there is only $7.5 \%$ of the original forest left and even so it still contains $2 \%$ of all botanic and vertebrate species of the planet [6]. However, due to its high degree of endemics, it is among the five most important hotspots of biodiversity [7], which makes it essential to understand the natural processes of regeneration through the knowledge of a soil seed bank.

All the viable seeds found in the soil are part of the seed bank [8], which is continually enlarged by the rain of seeds. Considering the Tropical Forests, the comprehension of seed 
germination in this bank is important to the understanding of how the vegetation grows back again in the degraded areas by the anthropic processes [9].

The germination of the seeds in the bank represents an important mechanism. After germinating and developing, they will be part of the regenerative stratum and later on be part of the grown individuals [10]. With that in mind, germination can be considered indicative of the resistance capability of a degraded ecosystem or the different successional stages of the forest [11].

Research and studies which procure the biodiversity preservation or regeneration in degraded areas of this ecosystem are of great importance to the preservation of Brazilian biodiversity. As such, the seed bank can clarify some aspects of ecophysiology of species and contribute to subsidize the regeneration work in degraded areas [12].

This work aimed to describe the contents of the seed bank by the identification of its seedlings, throughout the seasons of the year in the region of Atlantic Forest inside The Jureia- Itatins/Peruíbe Ecological Station in São Paulo state.

\section{Methodology}

\subsection{Placement and Characteristics of the Studied Area}

The study took place at Juréia-Itatins Ecological Station (EEJI) located in the south coastal area of São Paulo state, in the river valley of Ribeira de Iguape, which comprises municipal areas of Peruíbe and Iguape on the coastal side and Miracatu and Itariri in the country side. The size of the area is 79.270 acres and it is located between the parallels $24^{\circ} 17^{\prime}$ and $24^{\circ} 40^{\prime}$ and meridians $47^{\circ} 00^{\prime}$ and $47^{\circ} 30^{\prime}$ 'W [13], (Figure 1). The site chosen for the study inside the reserve (EEJI) was latitude $24^{\circ} 21^{\prime} 17,72^{\prime \prime}$ south and longitude $47^{\circ} 00^{\prime} 25,42^{\prime \prime}$. That is one of the largest protected areas of Atlantic Forest and it stands out due to its diversity of vegetation: it contains a Dense Ombrophylous Forest in its slopes (low lands, sub-montana and montana) and the native fluvial plants (hygrophila vegetation), marine (restinga) and fluvial-marine (mangrove) [14]. It also presents a potential connection with the Serra do Mar through a well-preserved 'continuuns' between the coastal and mountainous ecosystems. In the geomorphological context, Juréia is divided into three parts; mounts and slopes, Coastal Plains and beaches [15].

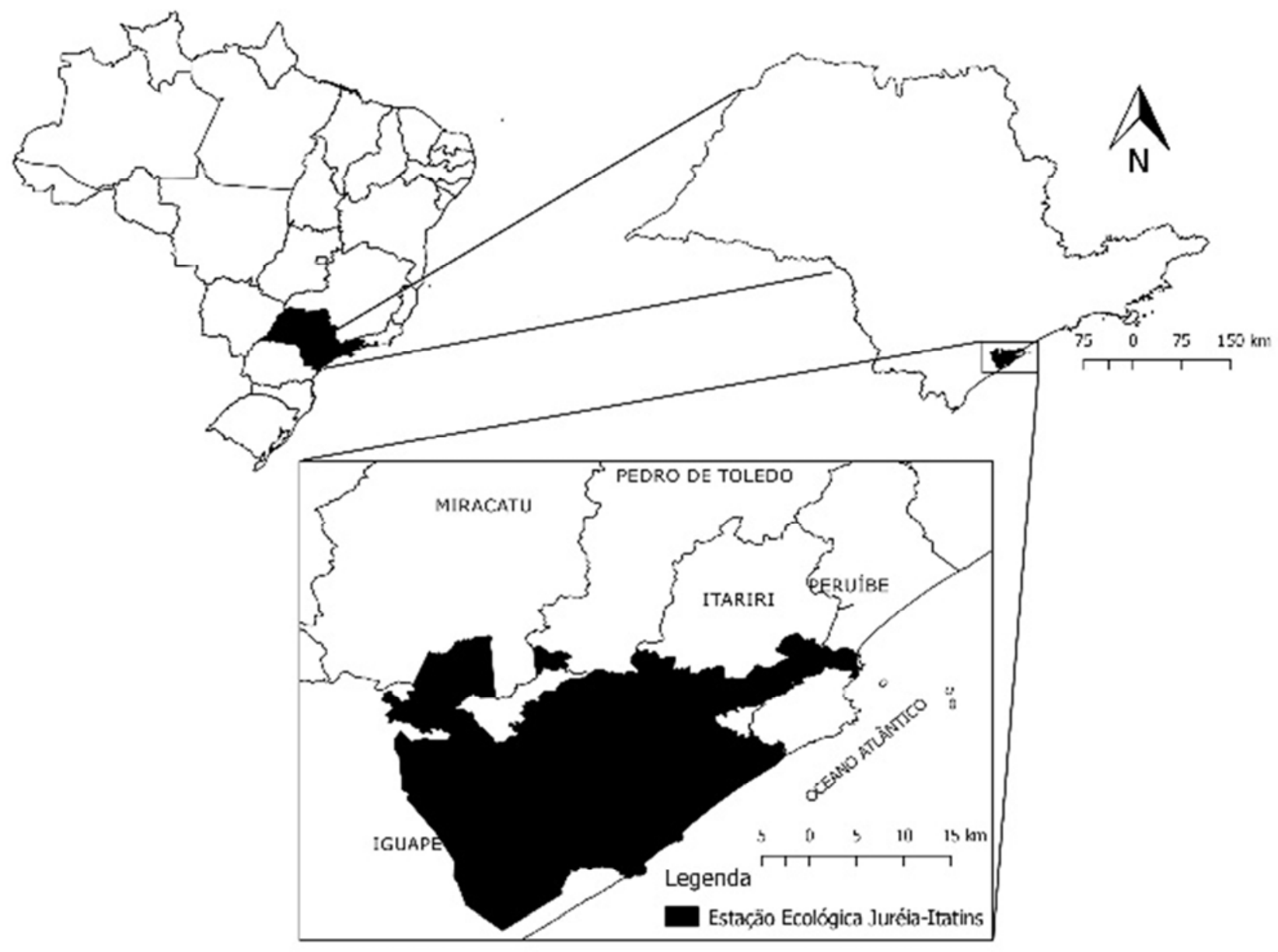

Figure 1. Localization of the Ecological Station of Juréia-Itatins, SP, Brazil.

The EEJI is characterized by complex vegetation and formed by different biomes, physiognomies and degrees of preservation, being among the few regions with zonations still preserved, from the beaches to the mounts. Derived from heterogeneity of relief, climate and soil, these zonations favor the appearance of specific vegetation forms in this region [16]. 
The climate is subtropical, humid, with undefined dry season and average rainfall of $2277,8 \mathrm{~mm}$ annually. There is a warm rainy season that goes from October to April (1714, 3 $\mathrm{mm})$ and another drier one from May to September $(563,5$ $\mathrm{mm})$. Highest average temperature occurs in February (25, $2^{\circ} \mathrm{C}$ ) and lowest in July $\left(17,8^{\circ} \mathrm{C}\right)$. Another important factor is the local climate variation derived from a considerable altitudinal gradient, such as the $1240 \mathrm{~m}$ of Morro das Três Pontas, surrounded by approximately $12 \mathrm{~km}$ of beaches in the Atlantic Ocean [14], [17].

\subsection{Seed Bank}

The collection of samples of soil was made in the indicated area in order to make it possible to compare the results in different seasons of the year. To assess the seed bank from the EEJI soil area samples of $20 \mathrm{~cm}$ x $20 \mathrm{~cm}$ x $20 \mathrm{~cm}$ (length, width, and depth) were collected with the help of a wooden template in a total of 12 samples of $0,096 \mathrm{~m}^{3}$ a month for 24 months. Randomly three sample repetitions were established with a distancing of approximately $3 \mathrm{~m}$ [18], [12]. The soil samples were accommodated in black polyethylene bags and promptly taken to the facility for the experiment in the greenhouse, with conditions of room temperature and light, at the Catholic University of Santos, São Paulo. The soil of each properly identified sample was revolved and distributed in three plastic trays, with the same dimensions and drainage, and the presence of a layer of vermiculite. Other three trays containing soil samples were sterilized in autoclave and randomly disposed among the others aiming to detect the contamination derived from the diaspores in the facility used for the experiment. The appearance of seedlings in the trays was observed for three months. The counting of the seedlings was initially done every day for 14 days and then every seven days for three months. The recognizable seedlings in the samples were transplanted to vases and later identified.

\section{Results and Discussion}

During the period of the study, the seed bank from the soil of EEJI presented approximately 77,3 seedlings emerging in a twelve-month period. The number of seedlings was approximately 67 seedlings $/ \mathrm{m}^{3}$ of soil by sample. The seed bank is one of the main sources of obtaining new individuals in initial phases of succession [19]. Many a time it is activated with the deforestation and has the capacity of covering a whole degraded area with no need of any intervention, so reducing the costs of recovery. In more dramatic cases such as burns, the removal of upper layers in the soil or the use of herbicides, the seed bank is usually eliminated from the surface, making the natural recovery harder and interventions, such as planting new seeds, necessary [1].

Awareness of the factors that control the dynamics of seed banks, such as compounds, density and the strategies of germination in every species are fundamental to the handling of ecosystems, succession studies and the recovery of suffering areas. The knowledge of the biology of seeds is essential to understand the processes of planting, succession of vegetation and natural regeneration. In spite of being the basic means of handling populations of plants, rare and little is the information available on the ecology and physiology of seeds from tropical forests [20], [21], mostly related to the identification of seedlings in the seed bank in the seasons of the year.

As for the analysis of the germination in the seed bank, in the summer and spring, as shown in figure 2, there were a greater number of seedlings. A smaller number was observed in the winter and autumn.

During the studies, there was no growth of seedlings in the trays that contained sterilized soil samples, which were used for the control of contamination.

In the samplings of summer and springtime, the appearance of seedlings happened on the 8th day of the experiment while in the samplings of winter and autumn there was a delay in the beginning of the development. The seedlings appeared in the 10th day. The dynamics of the seed bank might be affected by physical and chemical conditions of the environment and, consequently, influence the development of the seedlings [22]. As for the environmental conditions, the simultaneous effect of light, temperature, photoperiod or anoxia can be mentioned as propellers or not of the germination and mostly the development of seedlings [23].

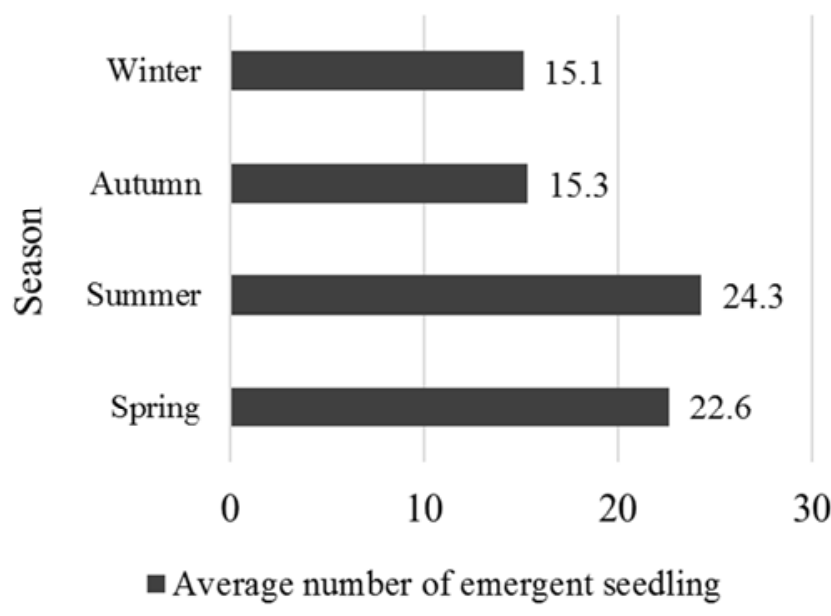

Figure 2. Average number of emergent seedlings in the soil samples of the Juréia Ecological Station in the Spring, Summer, Autumn and Winter seasons.

The percentages of botanical families in the seasons are presented in figures $3,4,5$ and 6 .

It is noticeable in figure 3 results that the highest percentage values in springtime, $46 \%$, belonged to species from the Urticaceae family and $27 \%$ from other species, which were the ones not taxonomically identified. The member of the Urticaceae family found was Cecropia sp.

In the summer, as figure 4 shows, 465 of species were from Urticaceae family (Cecropia sp) followed by $36 \%$ of members from the Melastomataceae family (Miconia $\mathrm{sp}$ ).

In the autumn samplings, figure 5 , the families that presented prevalence in the bank were Cannabaceae (Trema micranta) with $52 \%$. The families with the smallest 
percentages of seedlings were Cunoniacieae with $6 \%$.

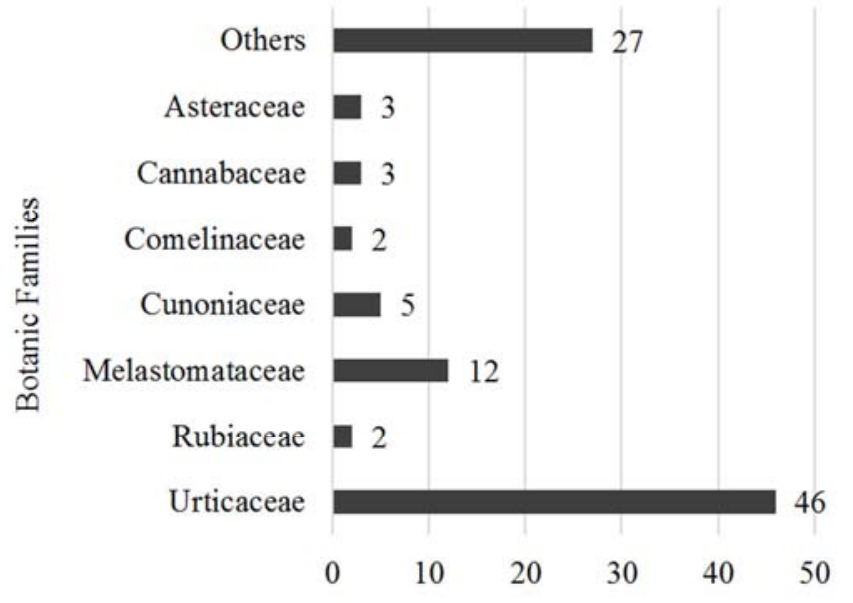

- Percentage of individuals by families at Spring

Figure 3. Percentage of individuals by families found in soil samples at Juréia- Itatins Ecological Station in the Spring.

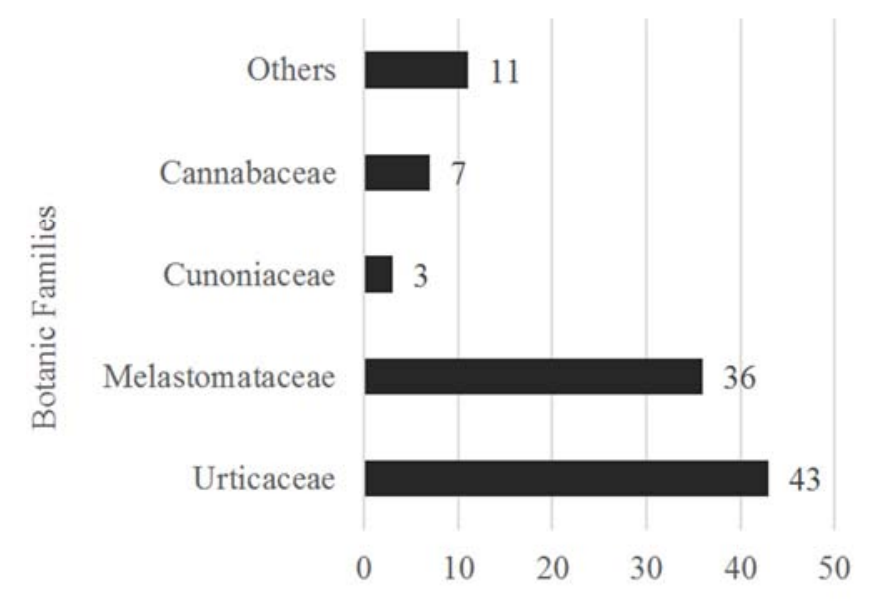

- Percentage of individuals by families at Summer

Figure 4. Percentage of individuals by families found in soil samples at Juréia Ecological Station in the Summer.

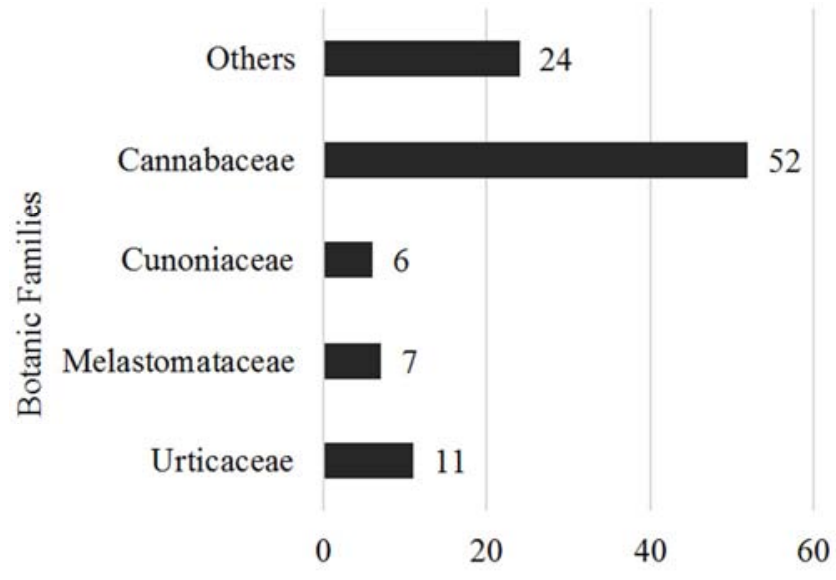

- Percentage of individuals by families at Autumn
The winter samplings, data in figure 6 , showed the smallest number of emerging seedlings in all of the experiment, being $18 \% \mathrm{f}$ the found individuals from the Cannabaceae family (Cecropia sp).

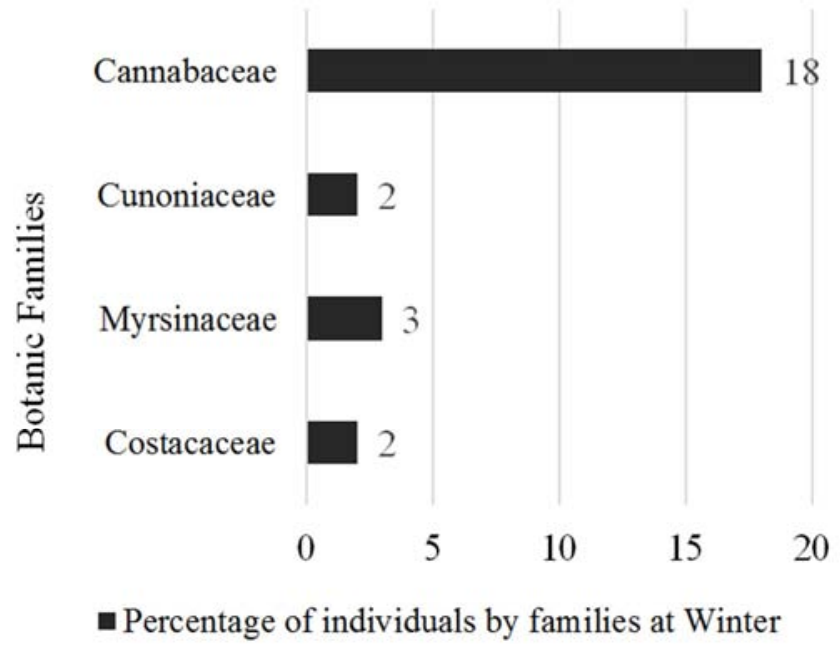

Figure 6. Percentage of individuals by families found in soil samples at Juréia Ecological Station in the Winter.

The amount of emerging seedlings in the different seasons of the year showed practically no significant statistical result in the number of seedlings between summer and spring, being spring the season with the highest number of seedlings. Therefore, the study reveals a predominance of individuals Cecropia sp (Urticaceae) in summer and spring and Trema micranta (Cannabaceae) in autumn and winter.

Those are pioneer species, characteristic in secondary formations. The presence of Cecropia sp and Trema $\mathrm{sp}$ in reforestation is positive since these species are responsible for the regeneration of the forest [24].

These results match those found in other works about the seed bank of tropical forests [25], [26], which show a prevalence of pioneer species in the seed bank of forest soil.

As for the morphospecies which were not identified, it is adamant to point out the little development of the seedlings as well as the few available identification catalogues. In an attempt to find the correct identification of every species found in the bank, longer observation time is required. That difficulty was met during the identification of the Cecropia sp, whose identification was only made possible after the appearance of its fifth pair of leaves. The correct identification of the seedlings through their leaves can be more difficult because their leaves might be distinctive in their shape, size, phyllotaxis or all of those characteristics at the same time [27].

Figure 7 displays the percentage of species found in the different seasons of the year. In fact, the families Urticaceae and Cannabaceae dominate in numbers, $40 \%$ and $30 \%$ respectively. They are species adequate for planting in open areas and those responsible for the recovery of the forest.

Figure 5. Percentage of individuals by families found in soil samples at Juréia Ecological Station in the Autumn. 


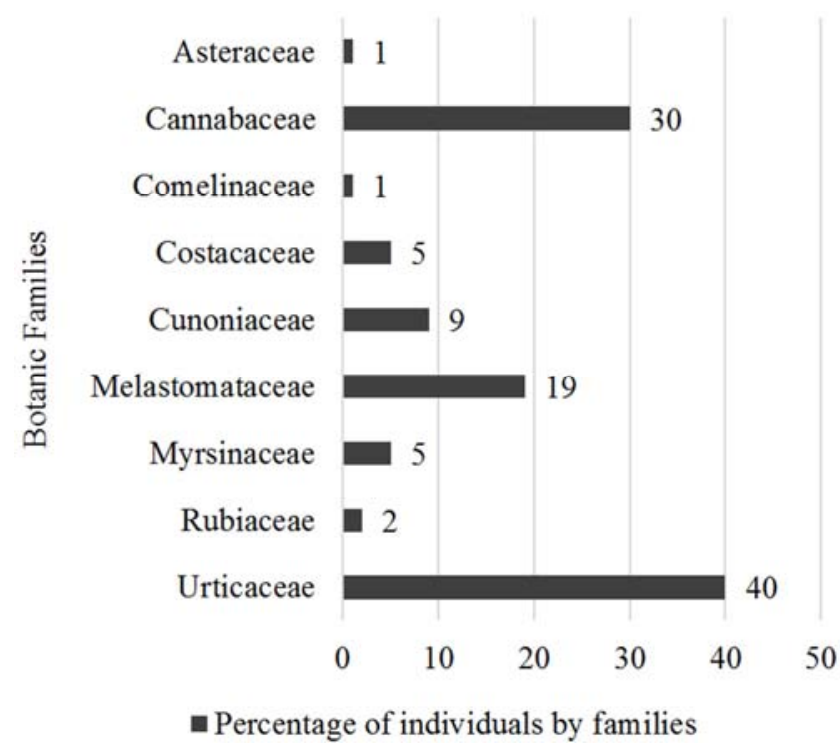

Figure 7. Percentage of individuals by families found in soil samples at Juréia Ecological Station in the Spring, Summer, Autumn and Winter seasons.

During the study, 45 morphospecies were observed. Those taxonomically identified are presented in table 1 . Same table shows the 6 families and species: Cannabaceae, Cunoniaceae, Melastomataceae, Myrsinaceae Rubiaceae, Urticaceae. Thirty-five morphospecies could not be identified in any taxonomic level. They have been stored in the herbal laboratory of botany in the Catholic University of Santos, São Paulo for future analysis

Table 1. Identified seedlings in soil samples from Juréia- Itatins Ecological Station.

\begin{tabular}{ll}
\hline Plant Families & Plant Species \\
\hline Canabaceae & Trema micranta $\mathrm{sp}$ \\
Cunoniaceae & Weinmannia $\mathrm{sp}$ \\
Melastomataceae & Miconia $\mathrm{sp}$ \\
Myrsinaceae & Mirsine $\mathrm{sp}$ \\
Rubiaceae & Psychotria $\mathrm{sp}$ \\
Urticaceae & Cecropia $\mathrm{sp}$ \\
\hline
\end{tabular}

The seed bank of a soil is the key element as source for biological knowledge about the vegetation history, also being responsible for the recovery of the forest through its regeneration potential [23], [28]. This bank is frequently formed by species that belong to early stages of succession and will be responsible for the building of a new ecosystem in case some impact or accident happens [23], [29].

The influence of the seasons of the year in the development of seedlings makes it evident the necessity of further studies that cover which season or seasons of the year are more appropriate for the transposition of soil, so it allows a higher number of emerging seedlings [30].

Amongst all the tropical ecosystems, the Atlantic Forest is the one in the most critical state of degradation [31].

The SOS MATA ATLANTICA Foundation and the National Institute of Spatial Research (INPE) released in May 2017 new data for the Atlantic Forest mapping. Data from the period 2015 to 2016 . Their discoveries show the deforestation of 29.075 acres or $290 \mathrm{~km}^{2}$ in the 17 states of the biome _ representing a raise of $57,7 \%$ in comparison to the previous period $(2014-2015)$ which was of 18.433 acres.

When the recovery of environments is intended, it is necessary to recover the vegetation as originally as possible, by having a good reference of the regional forest [19]. The reconstruction of degraded ecosystems involves diverse knowledge, mostly as functionality and dynamics of species are concerned, both essential to the structural basis of new communities [1].

The comprehension of seedlings from the seed bank of soil is important to subsidize the knowledge of the dynamics in the regeneration of species in areas of the Atlantic Forest. During the regeneration of EEJI, after a few natural disturbances, the seed bank is involved in the establishment of ecological groups and the recovery of richness of the pioneer species [32].

The knowledge of regional biodiversity is important and necessary for the development of models of handling and recovery that really contemplate the regeneration of the original biodiversity of that region. Thus, the use of biological methods in the recovery of degraded areas is the most efficient and economical way of doing it [1], [19].

The degradation of forest remains foreshadows changes in the characteristics of communities and the constitution of species [33]. Occasions in which clearings appear in the forest, caused by the fall or break of higher trees, for example, bring about new conditions of light and temperature favorable to the surge of shrubby-arboreal species more demanding of light [34]. As time goes by, there is the gradual replacement of the initial species by others, more tolerant to shadows. Therefore, the study of unaltered areas is essential to understand this complex behavior, with a higher emphasis in the ecological behavior of the components in the ecosystem [35].

The natural regeneration is part of this process and starts in the rain of seeds (dispersion) and in the seed bank, both mechanisms that guarantee the renovation [36].

Studies about seed banks of soil help in the comprehension of the dynamics involved in the recovery of the species which are part of the process. The further knowledge about the seed bank of EEJI must contribute to determine the distribution pattern and the abundance of pioneer species. Population studies are necessary in this unit of preservation, so ecophysiological aspects of the seeds, such as dispersion, initial establishment, growth and mortality rate can be assessed.

\section{Conclusion}

The results show the existence of a regenerative potential of the forest based on the observation of emerging seedlings in the seed bank. Seasons summer and spring presented a larger percentage of developed species. The same was not observed in autumn or winter. However, the presence of pioneer species could be observed in every season: Trema sp in autumn and winter and Cecropia sp in spring and summer. 


\section{Acknowledgements}

Our gratitude to the Forest Institute of São Paulo- Brazil and researcher Cláudio de Moura for his help in field outings and the identification of botanical material.

\section{References}

[1] D. S. Almeida, Recuperação da Mata Atlântica, Ilhéus: Editora Editus, 2000.

[2] S. L. Lewis, D. P. Edwards, D. Galbraith. Increasing human dominance of tropical forests. Science, vol. 349, 2015. pp. 827-832.

[3] A. R. MittermeieR, G. P. Robles, M. Hoffmann, J. Pilgrim, T. Brooks, C. G. Mittermeier, J. Lamoreux, G. A. B. Da Fonseca, P. A. Seligmann, H. Ford, S. A. De C. V. Cemex. "Hotspots revisited: earth's biologically richest and most endangered terrestrial ecoregions" 2004. Mexico City Cemex. pp. 390.

[4] H. Troppmair, Biogeografia e meio ambiente, Rio Claro, 2008. pp. 82.

[5] A. B. Pereira. Mata Atlântica uma abordagem geográfica, Nucleus, 2009, 8rd ed, vol. 6, pp. 27-52.

[6] D. C. Cabral, A. G. Bustamante, Metamorfoses florestais culturas, ecologias e as transformações históricas da Mata Atlântica, Editora: Prismas, 2016; pp. 460.

[7] N. M. Myers, R. A. Mittermeir, C. G. Fonseca, G. A. B. Kent, J. Biodiversity hotspots for conservation priorities, Nature, 2000, vol. 403 , pp. $854-858$.

[8] K. Thompson, J. P. Grime. Sectional variation in the seed banks of herbaceous species in ten contrasting habitats, Journal of Ecology, 1979, pp. 893-921. J. L. Harper. Population biology of plants. London: Academic Press, 1977, pp 892.

[9] J. L. Harper. Population biology of plants. London: Academic Press, 1977, pp 892.

[10] S. V. Martins, E. E. L. Borges, K. A. Silva. O banco de sementes do solo e sua utilização como bioindicador de restauração ecológica. In: S. V. Martins "Restauração ecológica de ecossistemas degradados" 2. Ed. -Viçosa, MG, Editora UFV, 2012. Cap. 10. Pp 291-330.

[11] L. F. S. Magnago, S. V. Martins, T. S. Venzke, N. M. Ivanauskas. Os processos e estágios sucessionais da Mata Atlântica como referência para restauração florestal. In: S. V. Martins (org.). "Restauração ecológica de ecossistemas degradados". 2012. Ed. UFV, Viçosa, pp. 69-100.

[12] M. Barberio, Barbosa, J. M, M. A. Rodrigues, N. A. Santos Junior. Estudo do banco de sementes em diferentes fisionomias de resting no litora sul de São Paulo. Acta Biológica Catarinense. 2014, Jun-Dez 1 (2), pp 28-35.

[13] J. C. M. T. Micheletti. Relações florísticas, estruturais e ecológicas entre as florestas do topo da Serra do Mar e as florestas de restinga no estado de São Paulo. 2007. Dissertação de Mestrado. São Paulo: Universidade de São Paulo,

[14] C. Moura. Caracterização da dinâmica da regenaração natural de duas fisionomias de Floresta Ombrófila Densa degradadas na Juréia, Litoral Sul/Vale do Ribeira, SP. Dissertação de (Mestrado em Ciências). 2016, Universidade Estadual de São
Paulo. SP, pp 110.

[15] C. R. G. Souza, A. P. Souza. Geologia e geomorfologia da área da Estação Ecológica juréia-itatins. in:” a. v. o. Marques, W. Duleba (Eds). "Estação Ecológica Juréia-Itatins: Ambiente físico, flora e fauna. 2004. Editoria Holos, Ribeirãp Preto. Cap. 2. pp 16-33.

[16] M. C. H. Mamede, Estação Ecológica Juréia-Itatins: ambiente físico, flora e fauna, Ribeirão Preto: Holos, 2004, pp. 115-132.

[17] J. F. Tarifa. Unidades Cilmáticas dos Maciços Litorâneos da Juréia-Itatins. In: A. V. O. Marques, W. Duleba (Eds). "Estação Ecológica Juréia-Itatins: Ambiente físico, flora e fauna". 2004. Editoria Holos, Ribeirãp Preto. Cap. 4; pp. 42-50.

[18] M. T. Grombone - Guaratini, e R. R. Rodrigues. "Seed bank and seed rain in a seasonal semi-deciduous forest in south-eastern Brazil". Journal of Tropical Ecology. 2002. Vol. 18, 00. 759-774.

[19] C. Scherer, J. A. Jarenkow. Banco de sementes de espécies arbóreas em floresta estacional no Rio Grande do Sul, Brasil, Revista Brasileira de Botânica, 2006. vol. 29 pp. 67-77.

[20] C. R. Vázquez-Yanes, A. Orozco-Segovia. Patterns of Seed Longevity and Germination in the Tropical Rain Forest. Annual Review of Ecology and Systematics. 1993. v. 24, pp. 69-87.

[21] C. Vasquez-Yanes, M. R. Aréchiga, M. R. "Ex Situ Conservation of Tropical Rain Forest Seeds: Problems and Perspectives". 1996. Ed. Interciência. v. 21, n. 5.

[22] U. N. Nielsen, T. Riis, H. Brix. The importance of vegetative and sexual dispersal of Luronium natans. Aquatic Botany, 2006. Vol. 84, 165-170.

[23] I. A. Ungar, Seed germination and seed-bank ecology in halophytes. In J. Kigel \& G. Galili (Eds). "Seed development and germination". 1995.. New York: Marcel Dekker. pp. 599-628.

[24] G. C. de S. Correia e S. V. Martins. Banco de Sementes do Solo de Floresta Restaurada, Reserva Natural. Vale, ES. Floresta e Ambiente. 2015. Vol. 22 (1). Pp. 79-87.

[25] S. Guevara - Sada. A. Gómez - Pompa. Determinación del contenido de semillas en muestras de suelo superficial de una selva tropical de Veracruz, México. In: Gómez -Pompa, A. et al. "Investigaciones sobre la regeneración de selvas altas en Veracruz, México". México: Continental, 1979. pp. $203-232$.

[26] N. Leal Filho. Caracterização do banco de sementes de três estádios de uma sucessão vegetal na Zona da Mata de Minas Gerais, MG. Dissertação (Mestrado em Ciência Florestal) Universidade Federal de Viçosa, Viçosa. 1992. pp. 116.

[27] G. R. Montoro. Morfologia de Espécies Lenhosas do Cerrado. Dissertação Pós Graduação do Departamento de Botânica na Universidade de Brasília. Brasília, DF. 2004. pp. 104.

[28] L. G. Roizman, Fitossociologia e dinâmica de sementes de populações arbóreas de florestas secundária em São Paulo, dissretação de mestrado, 1993. Universidade de São Paulo; pp 145 .

[29] S. V. Martins. Recuperação de áreas degradadas: ações em áreas de preservação permanente, taludes rodoviários e de mineração, Viçosa: Aprenda Fácil. 2009. pp. 270. 
[30] N. R. Vieira. O Papel do Banco de Sementes na Restauração de Restinga sob Talhão de Pinus elliottii Eng. 2004. Dissertação de Pós Graduação, Universidade Federal de Santa atarina. Florianópolis, SC; pp. 83.

[31] A. A. J. Tabanez, V. M. Viana, A. S. Dias. Consequências da fragmentação e do efeito de borda sobre a estrutura, diversidade e sustentabilidade de um fragmento de floresta de planalto de Pracicaba, SP, Revista Brasileira de Biologia, 1997, vol. 57, pp. 47-60.

[32] C. Baider, M. Tabarelli, W. Matovani, The soil seed bank during Atlantics Forest regeneration in southeast Brasil, São Carlos: Revista Brasileira de Biologia, 2001, vol. 61, pp. 35-44.

[33] M. Tabarelli, W. Mantovani, Clareiras naturais e a riqueza de espécies pioneiras em uma Floresta Atlântica Montana, Revista Brasileira de Biologia, 1999, vol. 59, pp. 251-261.

[34] D. C. M. Vieira, S. Gandolfo. Chuva de sementes e regeneração natural sob três espécies três espécies arbóreas emu ma floresta em processo de restauração, Revista Brasileira de Botânica, 2006, vol. 29, pp. 541-554.

[35] S. L. Caldato, P. A. Floss, D. M. Da Crosce, S. J. Longhi, Estudo da regeneração natural, banco de sementes e chuva de sementes na reserva genética florestal de Caçador, SC, Santa Maria: Revista Ciência Florestal, 1996, vol. 6, pp. 27-38.

[36] I. F. M. Válio, F. M. Scarpa. Germination of seeds of tropical pioneer species undercontrolled and natural conditions, Revista Brasileira de Botânica, 2001, vol. 24, pp. 79-84. 